\title{
Sociology of Terrorism and Counterterrorism: A Social Science Understanding of Terrorist Threat
}

\author{
Domenico Tosini*
}

University of Trento

\begin{abstract}
The purpose of this article is to outline a social science understanding of terrorist threat, with special reference to political violence of new terrorist groups, fundamentalist movements and extremist organisations such as Al-Qaeda. Four main terrorism topics will be examined: (i) Definition of terrorism. We will make explicit the political and moral implications of the word 'terrorism' by tracing a brief history of terrorism; at the same time, a definition of terrorism will be proposed based on an overview of terrorism studies. (ii) Typology of terrorism. The topic to be addressed here concerns the classification of terrorist groups, paying special attention to contemporary fundamentalist movements and extremist organisations (particularly after World War II). (iii) Explanation of terrorism. Criticism will be made of psychological explanations of terrorism that try to trace political violence back to specific personal traits or psychopathological profiles of terrorists. We will offer an alternative explanation, focusing on specific social, cultural and religious factors to be considered the root causes of terrorism. Suicide terrorism will be used as a case study. (iv) Counterterrorism policy. Here, we will discuss some of the limitations and counterproductive effects of the counterterrorism measures adopted by governments after 9/11, including new antiterrorism legislation, the case of special detention at Guantanamo Bay, and the Iraq invasion. Most of such limitations are due to a misunderstanding of the political culture and ideology of Islamic extremism and fundamentalism (Islamism). Some concluding remarks will summarise the findings of the article and underline the most important suggestions for a future research agenda in the sociology of terrorism and counterterrorism.
\end{abstract}

\section{Introduction}

After the events of 9/11 in New York and Washington, DC, and the attacks of 11 March 2004 in Madrid, and of 7 July 2005 in London, the new political threat posed by Al-Qaeda and other extremist movements has been highlighted by the media all around the world. Today, Western governments and their allies are confronted by widespread propaganda and the systematic organisation of political violence by a multitude of armed groups, whose aim is to challenge the fragile international (dis)order originating 
from the end of the Cold War. While Al-Qaeda (as well as terrorism) has a history that precedes the 9/11 attacks, specific factors, not least certain strategic errors in counterterrorism, have increased the tension between parts of the Islamic world and the West, provoking an escalation of violence that is currently continuing in different areas such as Afghanistan and Iraq. As a result, not only governments and civil society, but also social scientists, are being urged to analyse such phenomena, in order to identify the best solution for preventing violence.

This presupposes an accurate investigation whose main task is to understand, in sociological terms, why groups decide to use terrorism as a strategy for political struggle. Our primary purpose, therefore, should be to understand the rationale that drives terrorists, paying special attention to their calculations and beliefs. This is the only reliable way to establish an efficient system of counterterrorism. After all, knowledge is the best tool for a good policy. In this article, we shall offer an analysis of terrorism by considering four different questions: What is terrorism? How can we accurately classify terrorist movements? What leads political militants to choose political violence? What kinds of effects have been provoked by the counterterrorism measures adopted after 9/11? In recent years, all these questions have given rise to an unprecedented amount of publications in a field of research that still lacks uniformity at the conceptual and methodological levels (Vallis et al. 2006).

\section{Defining terrorism}

Groups resort to terrorism in order to acquire, maintain or extend political power over a society. Because of its use of violence, terrorism is seen as an unconventional strategy for political struggle, when compared with other forms that are generally adopted in a political regime, such as campaigning and voting during elections for various levels of government, and solving disputes through legal procedures (Tilly 2004). The term 'terrorism' was originally used to indicate violence inflicted by the dominant forces of a society, as during the Régime de la Terreur following the French Revolution (Garrison 2003, 2004; Laqueur 1997, 2002). The meaning developed in the nineteenth century in such a way to include violence outside the control of the state, such as the assassination of political leaders perpetrated by anarchists. Since then, the latter has become the most common meaning (Boyns and Ballard 2004; Nacos 2006). This partly reflects a specific political objective. Saying that terrorism is 'unconventional' implies a specific legal and political position, generally expressed by all states. They view the political activity of certain armed groups as an illegitimate form of obtaining and enforcing power. This rests on the fact that these groups break certain constitutional constraints. But, most importantly, they are labelled 'terrorists' because of their challenge to the monopoly of (the legitimate use of) political violence held by a state within a territory (Poggi 1990). 
This notwithstanding, terrorism should not be confused with 'normal' criminal activity. Unlike drugs, or car crime, or the Mafia, for example where the nature of the crimes involved implies that an individual is acting in his or her own egoistical, material or other kinds of personal interest - all actions defined as 'terrorist' are based on motivations that are mainly political (Garrison 2003; Nacos 2006). Thus, while it can seem morally senseless, it is perfectly correct from a descriptive point of view to argue that all terrorists are altruists (Hoffman 2006, 37). Having said that, one might then contend that terrorism is similar to war. After all, is not war an unconventional means of gaining power and, at the same time, 'a continuation of politics by other means' (Carl von Clausewitz)? However, there are differences between war and terrorism. In the states system of international relations, war has been accepted as a legitimate means to achieve a political end, so long as certain constraints are observed, such as those identified in the Geneva Conventions of 1949. While the idea that violent solutions to human relations should be even contemplated will be judged by some as absurd, within specific limits war continues to be seen as a justifiable form of political struggle. By contrast, terrorism is not seen in the same light. Why not?

Even though certain definitions approach the topic regardless of the nature of the victims targeted by political violence (Drake 1998; Garrison 2003 , 2004), a frequent answer to our question is that a specificity of terrorism is the use of violence against civilians or personnel not engaged in combat operations (Gunaratna and Steven 2004, 7; see also Rodin 2004). In both cases either of war or guerrilla war, violent actions are primarily directed against enemy's military forces engaged in combat operations. In other words, activities are bound by conventions entailing distinction between belligerents and neutrals, combatants and noncombatants, appropriate and inappropriate targets, legitimate and illegitimate methods (Rapaport 1977; Schmid 2004; see also Hoffman 2006). During a war, violence deliberately involving civilians can certainly happen. According to the International Criminal Court, such military operations should be considered 'war crimes', in that they violate the Geneva Conventions. In the same way, terrorism can be conceptualised as being 'the peacetime equivalent of war crimes' (cf. Cassese 2006; Schmid 2004). With this in mind, a rigorous analysis of armed groups should therefore distinguish between actions that are directed against military forces engaged in combat and actions that deliberately target civilians (and personnel not engaged in combat operations) (Cronin 2002); only the latter should be treated as terrorism (rather than perfunctorily naming both sets of actions as 'terrorist') (Goodwin 2006).

Of course, states, too, can kill and abuse civilians in peacetime - in this regard, the International Criminal Court is authorised to try state authorities accused of either genocide or 'crimes against humanity' such as torture or ethnic cleansing (International Criminal Court 1998). In the wake of 
the French Revolution, for example, the Reign of Terror (1793-1794) headed by Robespierre used indiscriminate violence against civilians. Thus, according to certain authors, these actions have to be included in a more comprehensive definition of terrorism (see, for example, Rodin 2004). However, it is now a convention to distinguish between illegitimate violence of states (inflicted from above), on the one hand, and that of small, clandestine non-state entities (inflicted from below), on the other (della Porta 2004), by naming the former 'state terror' (or terror) and the latter terrorism (Wilkinson 2001, 19; see also Grob-Fitzgibbon 2005). 'State terror' indicates the case in which states are directly engaged in terrorist activities. Another circumstance has to be distinguished, namely, 'state-sponsored terrorism', in which states are indirectly involved by financing, or offering intelligence and logistical assistance to, terrorist organisations (Hoffman 2006).

The use of violence against civilians (or personnel not engaged in combat operations) depends on a communicative and strategic component of terrorism. Apart from hurting or killing the victims who are the immediate targets of violence, a terrorist act also aims to generate a state of terror so as to influence other actors (Garrison 2003, 2004). As Brian Jenkins points out, 'terrorism is theatre' $(1976,4)$. Indeed, terrorism is used as a mean for attaining several objectives: for a demonstrative purpose in terms of public opinion (in order to focus people's attention on certain issues); for an intimidatory purpose in terms of that part of the population that has not been directly targeted (viewed as actors who might influence the government); for a coercive purpose in terms of the state (viewed as a target that is able to satisfy certain political demands); and, finally, for propaganda purposes in terms of the community, which is viewed as a target that might provide political support and whose interests a terrorist organisation wants to represent while competing with other organisations (Schmid and Jongman 1988, 28; see also Bloom 2005).

On the basis of the abovementioned distinctions, we propose to define terrorism as the use (or the threat) of violence against civilians (and personnel not engaged in combat operations) by non-state entities for specific political purposes.

\section{Exploring terrorism}

The second topic to be explored relates to the criteria to be adopted when attempting to classify the various forms of terrorism. We propose a typology based on a combination of political objectives and social cleavages. Both dimensions are among those most considered in the literature when describing different kinds of non-state organisations that resort to political violence (Schmid and Jongman 1988). The first dimension identifies a specific result or condition that terrorist groups want to achieve. The second dimension distinguishes the most important social divisions, between 
terrorist groups and their enemy, in terms of irreconcilable differences that undermine the possibility of sharing certain aspects of social life (such as a common nation, a common organisation of the state or a common set of moral rules). It seems appropriate to elaborate a more comprehensive analysis that associates the spectrum of political objectives, on the one hand, with that of social divisions, on the other. We examine some of the most important objectives and social divisions to be combined for a hypothetical phenomenology of contemporary terrorism.

One of the most crucial objectives is nationalism, which means that a group is struggling either for the liberation of a territory from occupying forces or for its independence (della Porta 1998; Grob-Fitzgibbon 2005; Gunaratna and Steven 2004; Post 2005). Nationalism can be combined with at least two cleavages. The first is ethnic and refers to somatic, linguistic or cultural differences between terrorists and their enemy (Gunaratna and Steven 2004; Stevens 2005). Examples of nationalist terrorism based on ethnic cleavages include the following: the Irgun Zvai Leumi, which fought against British forces for the independence of a Jewish state (1944-1947); the Front de Libération Nationale, which fought against French rule for the liberation of Algeria (1954-1962); the Palestine Liberation Organisation, which challenged the establishment of the state of Israel (1948); and also the better-known separatist campaigns of the Irish Republican Army in the Northern Ireland, the Basque Euskadi Ta Askatasuna in Spain, the Liberation Tigers of Tamil Eelam in Sri Lanka, and the Kurdistan Workers' Party (PKK) in Turkey (Hoffman 2006; Nacos 2006; Pape 2005; Pedahzur 2005; Wilkinson 2001). A second cleavage consists of ethnic plus religious differences (Hoffman 2006; Juergensmeyer 2000; Post 2005). Many recent nationalist movements fit this combination: the Lebanese Hezbollah, the Palestinian Hamas and the Islamic Jihad, each of them opposed to Israel; the Chechen and Kashmiri Separatists, seeking independence from Russia and India, respectively; and the Islamist terrorist network of Al-Qaeda and the Iraqi and Taliban insurgency groups, all of whom are engaged in a struggle for the liberation of Muslim lands from the military presence and influence of the USA and its allies (Gunaratna 2002; Pape 2005; Pedahzur 2005; Sageman 2004).

Fighting in a revolution is the second, most important political objective. A movement is revolutionary if its priority is to bring about a radical transformation of institutions in a pre-existing regime. This objective is generally associated with two cleavages. The first is ideological (della Porta 1998; Gunaratna and Steven 2004). Examples are the leftist armed groups: the Red Army Faction in Germany and the Red Brigades in Italy, both of which aimed to trigger a communist revolution in Western countries (della Porta 1995). The other cleavage is ethnic-religious. Numerous extremists have waged campaigns to overthrow secular regimes in the Muslim world in order to establish new, Islamic states. Examples are the Al-Gama'a Al-Islamiyya and the Islamic Jihad in Egypt, the Armed Islamic Groups in 
Algeria and the Jemaah Islamiyah in Indonesia (Gerges 2005; Kepel 2002; Phares 2005).

The third objective is 'vigilantism', that is, the attempt by individuals to defend by violence an established order with which they identify (Rosenbaum and Sedenberg 1974). Forms of ethnic vigilantism include that of paramilitary groups such as the Ulster Volunteer Force, the Red Hand Defenders, and the Loyalist Volunteer Force, all of them opposed to Catholic Republicans in Northern Ireland (della Porta 1998). Today, a variety of vigilante and racist groups are still active, for example, in the USA (Blee 2005). Alongside the ethnic vigilantism of the Ku Klux Klan are such groups as the Neo-Nazis, the Racist Skinheads and the NeoConfederates. A number of others associated with the Christian Identity movement can be classified as examples of an ethnic-religious variant of vigilantism (Southern Poverty Law Center 2006).

Religion can be combined with a fourth type of objective, which we characterise as symbolic, because of the tendency of certain terrorists to view their struggle as being a cosmic war between the forces of good (with which they identify themselves) and the forces of evil (which they oppose). A typical example of such movements is the Japanese cult of Aum Shinrikyo, which perpetrated the 1995 sarin gas attack on the Tokyo subway (Juergensmeyer 2000, Chapter 8). The final political objective to be mentioned relates to campaigns for specific, limited purposes. In this sense, one can speak of 'single-issue terrorism' (Nacos 2006, 74-89). An example is the battle against abortion by many American groups, such as the Army of God, since the legalisation of abortion in 1973. Certain sections of the animal rights movement, such as the Animal Liberation Front and the Earth Liberation Front, can also be classified under the same type of terrorism (Kushner 2003).

A concluding remark on our typology is necessary. All the forms of terrorism examined in this paper are ideal types (in Weberian parlance), which have been exemplified by certain empirical cases. But such cases are almost never a pure manifestation. They usually approximate to a type and, at the same time, have some traits belonging to other types. Hence, for example, the PKK is not only an ethnic and nationalist movement, but is also, to some extent, based on an ideological (Marxist) cleavage associated with a revolutionary objective. Moreover, Hezbollah, Hamas, Al-Qaeda and other jihadist groups, for example, are not only ethnic-religious and nationalist terrorists, but also revolutionary because of their project to establish Islamic regimes. Many other variants can be found in order to complete (and enrich) our typology, as shown in the following Table 1.

\section{Explaining terrorism}

How to explain terrorism is the next topic to be addressed. Our aim should be to clarify why certain (and not other) political groups and 
Table 1 A typology of contemporary terrorism, with examples

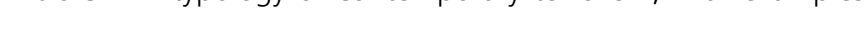

\section{Political objective}

\section{Social}

cleavage

Nationalist

\section{Revolutionary}

\section{Vigilante}

Symbolic

Single-Issue

Purely Irgun Zvai Leumi,

ethnic FLN, PLO, ETA, IRA, PKK, LTTE

Presence of revolutionary traits based on Marxist ideology: PKK as an example

KKK, Neo-Nazis, Racist Skinheads Neo-Confederates UVF, RHD, LVF

Presence of symbolic and mythical elements in some vigilante

Ethnic Hezbollah, Hamas, PIJ, religious Al-Qaeda, Chechen separatists, Kashmiri separatists, Iraqi insurgents, Taliban

Presence of revolutionary traits based on Islamist doctrine: Hamas, PIJ, Al-Qaeda, and

Taliban as examples GAI, EIJ, GIA, JI

\section{Presence of}

RAF, BR

anti-imperialist

elements in groups

such as RAF and BR

movements

Christian identity

Vigilante actions
for revolutionary
purposes based on
ideological cleavages
ideological cleavages
Presence of symbolic and mythical elements in movements such as Al-Qaeda

Aum Shinrikyo

Presence of eschatological elements to be found in several revolutionary movements based on ideological cleavages

Campaigns in defence of ethnic minorities: Black Panther as an example

\section{Antiabortion}

Movements: Army of

God as an example

\section{ALF, ELF}

ALF, Animal Liberation Front; BR, Red Brigades; EIJ, Egyptian Islamic Jihad; ELF, Earth Liberation Front; ETA, Basque Euskadi Ta Askatasuna; FLN, Front de Libération Nationale; GAl, Al-Gama'a Al-Islamiyya; GIA, Armed Islamic Groups; IRA, Irish Republican Army; JI, Jemaah Islamiyah; KKK, Ku Klux Klan; LTTE, Liberation Tigers of Tamil Eelam; LVF, Loyalist Volunteer Force; PIJ, Palestinian Islamic Jihad; PKK, Kurdistan Workers' Party; PLO, Palestinian Liberation Organisation; RAF, Red Army Faction; RHD, Red Hand Defenders; UVF, Ulster Volunteer Force. 
certain (and not other) individuals decide to use violence against civilians (and personnel not engaged in combat operations) in order to attain their goals. In other words, the challenge is to identify the most important factors leading to the adoption of terrorism as a strategy for political struggle. Some explanations try to focus on either a single factor or the same kind of factors. They are generally distinguished as monocausal explanations. But they rarely work, because the reality of terrorism (like all human behaviour) is too complex to be reduced in such a way. Examples are the theories of personality, which associate terrorism with specific psychopathological traits or processes such as narcissism and frustration. Such theories have encountered many criticisms. The view that a specific, terrorist abnormal personality exists and that psychological forces are the primary factors of political violence has been questioned in several occasions (Crenshaw 2000; Merari and Friedland 1985). These explanations, ironically, demonstrate a psychological mistake: they tend to attribute human actions to an individual state of mind, thus underestimating the circumstances of behaviour. By contrast, one should pay attention to the situation or context of the actions, rather than confining oneself to the investigation of psychological (internal) forces alone (Horgan 2005, Chapter 2). The best way is to consider the process of becoming terrorist and of engaging in terrorist activities as being a complex combination of psychological, social, ideological and cultural factors (Crenshaw 2000).

Searching for situational (external) factors is not immune from monocausal explanation. Consider the case of sociodemographic variables. It has been proven, for example, that it is no longer possible to rely on the high predictive capacity recognised in the past in terms of male gender, the fact of being a member of a poor social stratum, of having a low level of education, and of being single, as conditions for becoming a terrorist (Krueger and Maleckova 2003; Pape 2005). Some cases confute these explanations: the case of female suicide bombers belonging to organisations such as the Tamil Tigers and PKK; the case of the ringleader of the 9/11 commando, Muhammad Atta, a highly educated member of the upper-middle class; and the case of the ringleader of the 2005 London attacks, Muhammad Sadiq Khan, who was married with a child. Today, a more advanced explanation model is needed, one that addresses the rationale - which is a function of either political, economic, cultural or religious conditions - behind the decision to engage in terrorist activities (Moghadam 2006b; Pape 2005; Pedahzur 2004, 2005; Tosini 2007). To exemplify, suicide terrorism will be taken as a case study, as follows.

A single suicide attack can be defined as an act whose fulfilment requires and determines the death of (at least) one individual, who does not expect to survive the mission (Bloom 2005, 76; Moghadam 2006a; Pape 2005, 10; Pedahzur 2005, 10). The number of organisations setting out on suicide attacks has increased notably since suicide attacks were used in the 1980s by Hezbollah. According to our data set (which has been developed 
on the basis of a previous database arranged by Ami Pedahzur and Arie Perliger at the University of Haifa; see Pedahzur 2005; Tosini 2007), there were 835 suicide attack occurrences up to December 2005, claiming 11,689 deaths - with 375 attacks and 3888 deaths traced back to those mounted by Iraqi insurgents (especially by Al-Qaeda in Iraq and its allies) following the military invasion of Iraq in March 2003.

A better understanding of this development requires, first of all, a consideration of the political bases of terrorism, that is, its political objectives. One could characterise such suicide campaigns as Al-Qaeda's transnational terrorism against the USA and its allies as being a reaction to globalisation, westernisation, secularisation, democratisation or the growth of market capitalism (Cronin 2002). This kind of macro variables are certainly relevant not only because of the grievances they generally prompt. Globalisation of the financial markets and mass media communication, for example, are also important insofar as they offer unprecedented opportunities for terrorist activities themselves (Vallis et al. 2006).

However, in order to be more specific we should focus on the distinctive political conditions that trigger off terrorist attacks. In the case of suicide campaigns, occupation of territory and denial of independence seem to play a crucial role. Indeed, the escalation of suicide attacks between 1982 and 2005 is associated with two main types of nationalist campaigns. The first type is the liberation of certain territories from occupying forces: Hezbollah versus the USA, France and Israel (19821999); Hamas, the Al-Aqsa Martyrs' Brigades (Al-Fatah), Palestinian Islamic Jihad, and the Popular Front for the Liberation of Palestine versus Israel (since 1993); the Al-Qaeda network versus the USA and its allies around the world (since 1995); the Taliban versus the USA and its allies in Afghanistan (since 2001); and Iraqi insurgents versus the USA and its allies in Iraq (since 2003). Separatists form the second type of campaigns: the LTTE versus Sri Lanka (since 1987); the PKK versus Turkey (1996-2001); the Chechen Separatists versus Russia (since 2000); and the Kashmiri Separatists versus India (since 2000).

To investigate in more details the social mechanisms underlying (suicide) terrorism, we should pay attention to the reasons and actors' rationality associated with specific political, economic, cultural and religious conditions. This requires a multilevel analysis (Moghadam 2006b; Pedahzur 2004, 2005, 2006; Tosini 2007). There are at least three fundamental levels. The first concerns terrorist organisations, which should be treated as rational decisionmakers (Crenshaw 1998, 2000; della Porta 1995, Chapter 5). This implies a methodological approach that consists of analysing terrorism as a strategic choice (see Garrison 2003, 2004; Kalyvas 1999). As seen above, most of the armed groups that make use of suicide missions are engaged in nationalist campaigns (either for liberation or for independence). They calculate neither more nor less than anyone else in looking for the best way to attain their result. In the social sciences, such a way of processing information 
as a base for action is called instrumental rationality (Boudon 2003). The instrumental rationality of suicide attacks can be observed once the political context in which armed groups are acting is taken into account (Bloom 2005, 75-6; Bloom 2006; Elster 2005; Gambetta 2005). Among the specific circumstances leading a group to use extreme forms of political violence, such as suicide tactics, is the occurrence of an imbalance of power, that is, an asymmetry in terms of resources and combatants between groups and their enemy (Boyns and Ballard 2004, 10; Pape 2005, Chapter 3). The group leaders therefore resort to the higher degree of efficiency of suicide missions in comparison with other tactics, such as guerrilla warfare or improvised explosive devices.

At least three 'technical' advantages can be identified: the feasibility, thanks to disguise, of entering locations that are highly defended and thus difficult to destroy by conventional attacks - a tactic enhanced by the capacity to modify the direction of the weapon (i.e. the attacker) depending on the target's position (in this sense, suicide bombers are truly intelligent weapons); the impossibility, for the enemy, of obtaining information from attackers about their organisations, except when the attackers decide to abandon their missions and are captured; and the minimisation of the costs of attacker training, once it is noted that, in some cases, a few hours will suffice to provide the necessary instructions to execute the mission (Hoffman 2003).

The second level of analysis should focus on the community, whose (nationalist) interest a terrorist organisation wants to represent and defend. The community's role is crucial, in that it provides, or helps to find, important resources for armed groups, such as money, weapons, hiding places and, last but not least, militants (including those taking part in suicide missions). Achieving a consensus to provide these resources is rooted in different motivations. Three are cases of instrumental rationality. First of all, a community can be encouraged to support suicide terrorism through previous results achieved by a terrorist organisation, as was apparent in the case of the American and French withdrawal from Lebanon (due to the successful suicide attacks of Hezbollah in 1983). Second, armed groups can compensate for their community's costs, among them the costs of reprisals on the part of the enemy, by offering specific material rewards in the form of economic aid, such as those provided to suicide attackers' families by Hezbollah and Hamas (Levitt 2006). Third, this aid is often accompanied by symbolic rewards, in that organisations tend to confer prestige and an elevation of status not only on the individual militants who give their life, but also on all their family members (Pedahzur 2005).

A fourth motivation belongs to a different type of rationality, which rests on an unconditional assumption of certain principles or values. Sociologists call this type of motivation 'axiological rationality' (Boudon 2003). Indeed, many scholars stress the importance of taking into account the cultural bases of political violence (Moghadam 2006b; see also Vallis et al. 
2006). They consist of all beliefs that legitimise the use of, and the engagement in, extreme actions. As in any other society, the members of communities who support suicide terrorism share a set of beliefs that Jürgen Habermas has conceptualised as world life (Habermas 1985). In the case of suicide attacks, a crucial role is played by that part of world life consisting of a set of ideas and symbolic representations that justifies engaging in suicide missions and recognises the high value of a person's sacrifice for his or her community (Hafez 2006a; 2006b; Moghadam 2006b; Oliver and Steinberg 2005; Pedahzur 2004; Tosini 2007). We call this component of world life the culture of martyrdom. As documented in the cases of the Viet Cong and the LTTE, for example, not all organisations adopt religious beliefs (Weinberg 2006). It is nevertheless interesting that some religious interpretations, such as that of Al-Qaeda's Sunni radicalism calling for (a violent version of) jihad, are highly suited to inspiring a culture of martyrdom (Gerges 2005; Phares 2005; Sageman 2004).

The focus for the third and final level of analysis concerns the suicide attackers themselves. They reveal a complex constellation of possible motivations for joining suicide missions. The first is revenge. This is the pivotal motivation to be hypothesised, for example, in the case of the Chechen female attackers known as the 'Black Widows', the wives of rebels who had been killed by Russian military forces. A second factor is a status crisis, which means that potential attackers consider dying in a suicide mission as a better option than suffering a loss of reputation due to questionable behaviour, such as either adopting a wrong lifestyle (according to their religious beliefs) or committing actions that are condemned by their community. Some would-be suicide attackers living in Western countries (Khosrokhavar 2005) and Palestinian suicide bombers (Pedahzur 2005) fit this profile. To some extent, choosing this option is a form of instrumental rationality based on egoistic interest. Death is, of course, a high cost, but not so high as a loss of status: a suicide operation is a way to avoid or compensate for this loss. The prestige associated with being martyred (at the service of the political or religious cause of the attackers' community) purifies the attacker from all past wrongdoings. In spite of criticisms of pure psychological explanations of terrorism, mechanisms such as loss of status suggest the importance of keeping the study of political violence open to the analysis of psychological processes and 'facilitating traits', which predispose certain individuals to embrace extremism (Vallis et al. 2006).

Other cases of instrumental rationality are based on altruistic interest. Here, taking part in a suicide attack aims primarily at helping either family members or all the members of a community. In the first case, militants give their life knowing that terrorist organisations will provide their family with some level of economic aid (Levitt 2006). In the second case, attackers' reasons are strategic - neither more nor less than those of the organisations' leaders. Attackers consider their mission as the best means to liberate or 
defend their community. Of course, the difference is that they will not individually benefit from their action. They identify themselves with their community and are willing to sacrifice themselves for the community's cause (Tosini 2007, Chapter 4). A final motivation to be mentioned fits the category of axiological rationality. In this case, militants have deeply interiorised the values and principles of the culture of martyrdom and are driven by the duty to die, as commended by their beliefs, independently of the consequences to which this behaviour can lead (Hafez 2006a, 2006b; Moghadam 2006b; Oliver and Steinberg 2005; Pedahzur 2005). This is clearly an example of altruistic suicide (Durkheim 1951). Many videotapes of suicide bombers belonging to jihadist movements such as Hezbollah, Hamas and Al-Qaeda, for example, document the fact that this duty and their beliefs are fundamental elements in explaining (along with the other factors mentioned above) the decision to take part in a suicide operation (Tosini 2007, Chapter 4). As we will see in the next section, awareness of this specific, political culture is a crucial tool in devising an adequate counterterrorism policy.

\section{Evaluating counterterrorism}

A scientific analysis of terrorism can contribute to the evaluation of counterterrorism strategies. There are two ways to approach counterterrorism. The first concerns its impact on ethic and legal constraints, that is, its lawfulness or unlawfulness. Since terrorism is evidently a radical threat to security, all states usually resort to special countermeasures. Typically taking the form of a state of emergency, these measures tend to circumvent some of the boundaries protecting human rights. Since 9/11, even regimes that are unquestionably liberal, such as the USA and the UK, have introduced new, tough antiterrorism legislation. The American Congress, for example, passed in October 2001 a new statute known as the USA Patriot Act (US Congress 2001). Several organisations, such as the American Civil Liberties Union, have criticised provisions in the Act that give the FBI the power to obtain from libraries information about users (who may be unaware of this power) and to search houses without a warrant (Whitehead and Aden 2002). In the UK, the government adopted in November 2001 a statute called The Anti-Terrorism, Crime and Security Act (UK Parliament 2001), which was later ruled as illegitimate by the House of Lords in December 2004 (House of Lords 2004), in that, through such a statute, the government could indefinitely jail without charge those who, among foreign nationals, were suspected of being members of terrorists groups, thereby (according to the Lords) discriminating against such people.

At the international level, special attention has been paid to the case of Guantanamo Bay, the American prison camp in Cuba where the Bush administration has incarcerated hundreds of terrorist suspects under the 
jurisdiction of special military tribunals (US President 2001). For more than 5 years, these suspects have experienced a system of indefinite detention without charge and the factual impossibility of having access to ordinary courts. In June 2004 and June 2006, the US Supreme Court ruled such detention illegitimate, by arguing for the right of all Guantanamo detainees to be tried by ordinary (instead of military) American tribunals (US Supreme Court 2004, 2006). The treatment of suspects has been judged - by several international organisations such as Amnesty International (2005) and by the United Nations (Hoge 2006) - to be in violation of the Geneva Conventions. These and other violations have been reported by many experts (Dworkin 2002a, b). Numerous criticisms relating to the violation of international law have also been provoked by the invasion of Iraq in March 2003 as a result of the Bush doctrine of preventive war (Habermas 2006; Sands 2005).

All these ways of analysing counterterrorism focus on legal considerations alone. However, there is a different approach, which covers the efficacy of counterterrorism and its strategic rather than legal implications. Post-9/ 11 counterterrorism is beginning to reveal its strategic limitations, and it is time to learn at least three important lessons. As seen above, political violence is a strategy that is used to achieve political goals. In the case of Al-Qaeda, for example, it is the liberation of Muslim lands from the military occupation by, and the political influence of, Western countries (Pape 2005; Pedahzur 2005; Tosini 2007). As stated by the 7 July London bomber, Shehzad Tanweer, in the Al-Qaeda film of 8 July 2006: 'What you have witnessed now is only the beginning of a series of attacks, which, inshallah, will intensify and continue, until you pull all your troops out of Afghanistan and Iraq, until you stop all financial and military support to the USA and Israel, and until you release all Muslim prisoners from Belmarsh and your other concentration camps' (Al-Qaeda Film 2006). Here is the rationale of the new jihadist terrorism of the 21st century, however irrational and fanatical it may seem to the West. In 1983, Hezbollah used suicide missions to compel the USA and France to withdraw from Lebanon. Since then many other organisations, including Al-Qaeda, have learned their lesson and resorted to this tactic. Between March 2003 and December 2005, I found that Iraqi groups alone (particularly Al-Qaeda in Iraq) perpetrated around 400 suicide attacks, killing nearly 3900 people (equivalent to a second 9/11). In Afghanistan, too, suicide terrorism is growing. Hence, the first lesson for Western governments is simple, but crucial: do not occupy other people's lands. The more you do so, the more (suicide) terrorism will increase - both inside those territories and within Western countries. All the available data demonstrate this tendency.

The second lesson relates to the use of emergency powers and the violence of war. Western countries have to take seriously the evidence that abuses committed by governments and military personnel are subsequently 
used in terrorist propaganda, propelled and disseminated by new media. It is not simply a matter of adhering to the rule of law. There are also strategic implications. These can be seen in the message 'Invitation to Islam' aired on 2 September 2006 by an American Al-Qaeda member, Adam Gadahn, where counterterrorism misconduct, such as that in Guantanamo and Abu Ghraib, has become an instrument of rhetoric for convincing young Americans or Europeans to convert to Islamism and join the jihad against Western civilisation (Gadahn 2006). Apologists for the emergency powers and the invasion of Iraq may argue that this terrorism is such a deadly threat to our way of life that extreme measures are necessary. In this view, illegal detention, 'collateral damage' and 'extraordinary renditions' are all acceptable risks to be run in the pursuit of ultimate victory.

But there are facts that contradict this assumption. Here is the third and most important lesson. The West's counterterrorism policy misunderstands the political culture of the Al-Qaeda militants. We often say that this terrorism differs from that of the Irish Republican Army, of Euskadi Ta Askatasum, of the Red Army Faction, or of the Red Brigades. But what point is being made here? How can groups such as Al-Qaeda recruit so many young people ready to give their lives for the cause? As we have shown in the preceding section, the answer is: by promoting the value of martyrdom, which is viewed as the noblest way of life. Whereas western society speaks, referring to itself, of a crisis of values, elsewhere people embrace the strongest possible commitment: renouncing self-preservation in the struggle against enemies who threaten their nations or culture. To quote Shehzad Tanweer again: "We are a hundred per cent committed to the cause of Islam. We love death the way you love life. I tell all you British citizens to stop your support to your lying British government, and to the so-called "war on terror", and ask yourselves why would thousands of men be willing to give their lives for the cause of Muslims' (Al-Qaeda Film 2006). To deal with this kind of terrorism, extreme measures such as torture and other forms of violence, including military campaigns, have a limited deterrent effect. They are rather an invitation to those seeking martyrdom. All contexts of violence, such as armed struggle, are indeed the perfect condition for those who love martyrdom. Taking part in violence is, for them, the finest way to fulfil their duty and gain respect from their community.

\section{Concluding remarks}

At the beginning of the third millennium, terrorism is adopting new, destructive forms, as witnessed in the 9/11 attacks and the escalation of bloody (daily) bombings against innocent civilians in Iraq. As social scientists, our most important task is to investigate this phenomenon in such a way as to clarify its logic and, thus, to make a contribution to the 
prevention of future violence. Since terrorism is a human phenomenon, the purpose of identifying its logic implies, more precisely, that we have to focus on its rationale, which in turn means that terrorists' motivations, reasons and rationality should become our main focus of attention.

Terrorism is the use (or the threat) of violence against civilians (and personnel not engaged in combat operations) by non-state entities for political purposes. As seen in our typology, based on combinations of political objectives and social cleavages, there is a wide variety of forms of terrorism. Today, the most aggressive manifestations are the result of nationalist goals and ethnic and/or religious differences between terrorists and their enemies. Some current campaigns, such as those of the LTTE, Al-Qaeda, the Taliban, and the Iraqi insurgency, for example, fit this profile of contemporary terrorism.

Understanding terrorists' logic requires us to distinguish the many variables associated with actors who are engaged in the use of political violence. By taking suicide terrorism as a case study, we have identified three levels concerning terrorists' rationale: the strategy of terrorist organisations, which favour an instrumental use of suicide missions; the political, economic, symbolic and cultural factors from which a community's consensus is built; and, finally, the constellation of attackers' motivations, the most relevant being revenge, status crisis, economic aid for the attackers' family, the attackers' identification with the community's cause, and their unconditional commitment to a culture of martyrdom.

All these provide crucial information for developing an adequate response to terrorism. Counterterrorism has two types of implications. Current responses have given rise to many ethical and legal violations of human rights. This is the first kind of limitations to be denounced by sociological (and legal) scholars. In addition, empirical investigations warn us of three strategic limitations concerning the efficacy of counterterrorism as currently practised. These are fomenting the nationalism of terrorists by military occupation of their lands; underestimating the power of terrorist propaganda relating to human rights violations caused by antiterrorism measures; and, finally, fuelling militants' aspiration to achieve martyrdom by creating the violent conditions endemic in the use of military options as a counterterrorism solution.

\section{Short Biography}

Domenico Tosini is a Researcher at the University of Trento (Italy). His research is located at the intersection of political sociology and sociology of law; he has authored papers in these areas for Sociologia del diritto, Quaderni di Sociologia, Studi di Sociologia, International Journal of the Sociology of Law, Contemporary Sociology and Social Science Information. His book Terrorismo e antiterrorismo nel XXI secolo [Terrorism and Counterterrorism in the Twenty-First Century] (Laterza, 2007) argues for a sociological 
understanding of the rationale behind the terrorist campaigns, with special reference to the sociological analysis of suicide terrorism. Current research involves both theoretical and empirical research on the political culture of Islamist groups such as Al-Qaeda.

\section{Note}

* Correspondence address: University of Trento, Department of Sociology and Social Research, Facoltà di Sociologia, Piazza Venezia 41, 38100 Trento, Italy. Email: domenico.tosini@unitn.it.

\section{References}

Al-Qaeda Film 2006. 'Al-Qaeda Film on the First Anniversary of the London Bombings.' MEMRI TV, 8 July 2006, http://www.memritv.org/Transcript.asp?P1=1186 (last accessed 5 September 2006).

Amnesty International 2005. AI Report 2005, http://web.amnesty.org/report2005/message-eng (last accessed 25 May 2005).

Blee, Kathleen M. 2005. 'Women and Organized Racial Terrorism in the United States.' Studies in Conflict and Terrorism 28: 421-33.

Bloom, Mia 2005. Dying to Kill. New York, NY: Columbia University Press.

Bloom, Mia 2006. 'Dying to Kill: Motivations for Suicide Terrorism.' Pp. 25-53 in Root Causes of Suicide Terrorism, edited by Ami Pedahzur. London: Routledge.

Boudon, Raymond 2003. 'Beyond Rational Choice Theory' Annual Review of Sociology 29: 121.

Boyns, David and James David Ballard 2004. 'Developing a Sociological Theory for the Empirical Understanding of Terrorism.' American Sociologist 35: 5-26.

Cassese, Antonio 2006. 'The Multifaced Criminal Notion of Terrorism in International Law.' Journal of International Criminal Justice 4: 933-58.

Crenshaw, Martha 1998. 'The Logic of Terrorism: Terrorist Behaviour as a Product of Strategic Choice.' Pp. 7-24 in Origin of Terrorism, edited by Walter Reich. Washington, DC: Woodrow Wilson Center Press.

Crenshaw, Martha 2000. 'The Psychology of Terrorism: An Agenda for the 21st Century.' Political Psychology 21: 405-20.

Cronin, Audrey Kurth 2002. 'Behind the Curve: Globalization and Terrorism.' International Security 27: 30-58.

della Porta, Donatella 1995. Social Movements, Political Violence and the State: A Comparative Analysis of Italy and Germany. Cambridge, UK: Cambridge University Press.

della Porta, Donatella 1998. 'Il Terrorismo nel Mondo Contemporaneo.' Enciclopedia delle Scienze Sociali [Enciclopedia Treccani, Roma] 8: 597-604.

della Porta, Donatella 2004. 'Terror Against the State.' Pp. 208-16 in The Blackwell Companion to Political Sociology, edited by Kate Nash and Alan Scott. Oxford, UK: Blackwell Publishing.

Drake, C. J. M. 1998. Terrorists' Target Selection. New York, NY: St. Martin's Press.

Durkheim, Émile 1951. Suicide. New York, NY: Free Press.

Dworkin, Ronald 2002a. 'The Threat to Patriotism.' New York Review of Books 49: 28 February 2002 http://www.nybooks.com/articles/15145 (last accessed 5 May 2005).

Dworkin, Ronald 2002b. 'The Trouble with the Tribunals.' New York Review of Books 49: 25 April 2002, http://www.nybooks.com/articles/15284 (last accessed 5 May 2005).

Elster, Jon 2005. 'Motivations and Beliefs in Suicide Missions.' Pp. 233-58 in Making Sense of Suicide Missions, edited by Diego Gambetta. Oxford, UK: Oxford University Press.

Gadahn, Adam 2006. 'Al-Qaeda: An Invitation to Islam.' As-Sahab, 2 September 2006, http://www.lauramansfield.com/j/zawahiri090106.asp. (last accessed 3 September 2006).

Gambetta, Diego 2005. 'Can We Make Sense of Suicide Missions?' Pp. 259-89 in Making Sense of Suicide Missions, edited by Diego Gambetta. Oxford, UK: Oxford University Press. 
Garrison, Arthur H. 2003. 'Terrorism: The Nature and Its History.' Criminal Justice Studies 16: 39-52.

Garrison, Arthur H. 2004. 'Defining Terrorism: Philosophy of the Bomb, Propaganda by Deed and Change Through Fear and Violence.' Criminal Justice Studies 17: 259-79.

Gerges, Fawaz A. 2005. The Far Enemy: Why Jihad Went Global. Cambridge, UK: Cambridge University Press.

Goodwin, Jeff 2006. 'A Theory of Categorical Terrorism.' Social Forces 84: 2027-46.

Grob-Fitzgibbon, Benjamin 2005. 'What is Terrorism? Redefining a Phenomenon in Time of War.' Peace and Change 30: 231-46.

Gunaratna, Rohan 2002. Inside Al-Qaeda. New York, NY: Penguin.

Gunaratna, Rohan and Graeme C. S. Steven 2004. Counterterrorism. Santa Barbara, CA: Abc Clio.

Habermas, Jürgen 1985. Theory of Communicative Action. Boston, MA: Beacon Press.

Habermas, Jürgen 2006. The Divided West. Cambridge, UK: Polity Press.

Hafez, Mohammed M. 2006a. 'Rationality, Culture, and Structure in the Making of Suicide Bombers: A Preliminary Theoretical Synthesis and Illustrative Case Study.' Studies in Conflict and Terrorism 29: 165-85.

Hafez, Mohammed M. 2006b. 'Dying to Be Martyrs: The Symbolic Dimension of Suicide Terrorism.' Pp. 54-80 in Root Causes of Suicide Terrorism, edited by Ami Pedahzur. London: Routledge.

Hoffman, Bruce 2003. 'The Logic of Suicide Terrorism.' Atlantic Monthly, June 2003, http:// www.theatlantic.com/doc/200306/hoffman (last accessed 31 October 2005).

Hoffman, Bruce 2006. Inside Terrorism. New York, NY: Columbia University Press.

Hoge, Warren 2006. 'U.N. Report Calls for End to Guantanamo Detentions.' New York Times, 16 February 2006, http://www.nytimes.com/packages/pdf/international/20060216gitmo_ report.pdf (last accessed 16 February 2006).

Horgan, John 2005. Psychology of Terrorism. London: Routledge.

House of Lords 2004. A (FC) and others (FC) Appellants v Secretary of State for the Home Department (Respondent), [2004] UKHL 56, 16 December 2004, http://www.publications. parliament.uk/pa/ld200405/ldjudgmt/jd041216/a\&oth-1.htm (last accessed 20 March 2007).

International Criminal Court 1998. Rome Statute. The Hague: Public Information and Documentation Section of the International Criminal Court. http://www.icc-cpi.int/library/ about/officialjournal/Rome_Statute_120704-EN.pdf (last accessed 10 June 2006).

Jenkins, Brian 1976. International Terrorism: A New Mode of Conflict. Research Paper n. 48, California Seminar on Arms Control and Foreign Policy.

Juergensmeyer. Mark 2000. Terror in the Mind of God. Berkeley, CA: University of California Press.

Kalyvas, Stathis N. 1999. 'Wanton and Senseless? The Logic of Massacres in Algeria.' Rationality and Society 11: 243-85.

Kepel, Gilles 2002. Jihad: The Trail of Political Islam. Cambridge, MA: Harvard University Press.

Khosrokhavar, Farad 2005. Suicide Bombers. London: Pluto Press.

Krueger, Alan B. and Jitka Maleckova 2003. 'Education, Poverty and Terrorism: Is There a Causal Connection?' Journal of Economic Perspectives 17: 119-44.

Kushner, Harvey W. 2003. Encyclopedia of Terrorism. London: Sage.

Laqueur, Walter 1997. The Age of Terrorism. Boston, MA: Little Brown.

Laqueur, Walter 2002. A History of Terrorism. New Brunswick, NJ: Transaction Publishers.

Levitt, Matthew 2006. Hamas: Politics, Charity, and Terrorism in the Service of Jihad. Washington, DC: Washington Institute for Near East Policy.

Merari, Ariel and Nehemia Friedland 1985. 'Social Psychological Aspects of Political Terrorism.' Applied Social Psychology Annual 6: 185-205.

Moghadam, Assaf 2006a. 'Defining Suicide Terrorism.' Pp. 13-24 in Root Causes of Suicide Terrorism, edited by Ami Pedahzur. London: Routledge.

Moghadam, Assaf 2006b. 'The Roots of Suicide Terrorism: A Multi-Causal Approach.' Pp. 81-107 in Root Causes of Suicide Terrorism, edited by Ami Pedahzur. London: Routledge. Nacos, Brigitte L. 2006. Terrorism and Counterterrorism. New York, NY: Pearson Longman.

Oliver, Anne Marie and Paul Steinberg 2005. The Road to Martyrs' Square. Oxford, UK: Oxford University Press. 
Pape, Robert A. 2005. Dying to Win. New York, NY: Random House.

Pedahzur, Ami 2004. 'Toward an Analytical Model of Suicide Terrorism - A Comment.' Terrorism and Political Violence 16: 841-44.

Pedahzur, Ami 2005. Suicide Terrorism. Cambridge, UK: Polity Press.

Pedahzur, Ami (ed.) 2006. Root Causes of Suicide Terrorism. London: Routledge.

Phares, Walid 2005. Future Jihad. New York, NY: Palgrave.

Poggi, Guanfranco 1990. The State. Stanford, CA: Stanford University Press.

Post, Jerrold M. 2005. 'The New Face of Terrorism: Socio-Cultural Foundations of Contemporary Terrorism.' Behavioural Sciences and the Law 23: 451-65.

Rapaport, David 1977. 'The Politics of Atrocity.' Pp. 46-61 in Terrorism: Interdisciplinary Perspectives, edited by Yonah Alexander and Seymour Finger. New York, NY: John Jay Press.

Rodin, David 2004. 'Terrorism Without Intention.' Ethics 114: 752-71.

Rosenbaum, Ron H. and Peter C. Sedenberg 1974. 'Vigilantism.' Comparative Politics 6: 54170.

Sageman, Marc 2004. Understanding Terror Networks. Philadelphia, PA: University of Pennsylvania Press.

Sands, Philippe 2005. Lawless World. London: Allen Lane, Penguin Books.

Schmid, Alexander P. 2004. 'Frameworks for Conceptualising Terrorism.' Terrorism and Political Violence 16: 197-221.

Schmid, Alexander P. and Albert J. Jongman 1988. Political Terrorism. London: Transaction Publishers.

Southern Poverty Law Center 2006. Intelligence Report 2005 - Active US Hate Groups in 2005, http://www.splcenter.org/intel/map/hate.jsp (last accessed 5 July 2006).

Stevens, Michael J. 2005. 'What Is Terrorism and Can Psychology Do Anything to Prevent It?' Behavioural Sciences and the Law 23: 507-26.

Tilly, Charles 2004. 'Terror, Terrorism, Terrorist.' Sociological Theory 22: 5-16.

Tosini, Domenico 2007. Terrorismo e Antiterrorismo nel XXI Secolo. Roma-Bari: Laterza.

UK Parliament 2001. Anti-Terrorism, Crime and Security Act, 2001 (Chapter 24) http:// www.opsi.gov.uk/acts/acts2001/20010024.htm (last accessed 25 May 2005).

US Congress 2001. Uniting and Strengthening America by Providing Appropriate Tools Required to Intercept and Obstruct Terrorism (USA Patriot Act). Public Law 107-56, 107th Congress, 26 October 2001, http://files.findlaw.com/news.findlaw.com/hdocs/docs/terrorism/patriotact.pdf (last accessed 25 May 2005).

US President 2001. Military Order Detention. Treatment, and Trial of Certain Non-Citizens in the War against Terrorism. White House Press Release, 13 November 2001, http://www.whitehouse.gov/news/releases/2001/11/20011113-27.html (last accessed 20 May 2007).

US Supreme Court 2004. Rasul v. Bush, 124 S. Ct. 2686, 28 June 2004, http://laws.findlaw.com/us/000/03-6696.html (last accessed 20 May 2007).

US Supreme Court 2006. Hamdan v. Rumsfeld, 2006 WL 1764793 (US), 29 June 2006, http:// laws.findlaw.com/us/000/05-184.html (last accessed 20 May 2007).

Vallis, Rhyll, Yubin Yang and Hussein A. Abbas 2006. 'Disciplinary Approaches to Terrorism: A Survey.' ALAR - The Artificial Life and Adaptive Robotics Laboratory: Technical Reports, TRALAR-200611015. http://seal.tst.adfa.edu.au/ alar/techreps/200611015.pdf (last accessed 20 July 2007).

Weinberg, Leonard 2006. 'Suicide Terrorism for Secular Causes.' Pp. 108-21 in Root Causes of Suicide Terrorism, edited by Ami Pedahzur. London: Routledge.

Whitehead, John and Steven H. Aden 2002. "Forfeiting "Enduring Freedom" for "Homeland Security": A Constitutional Analysis of the USA Patriot Act and the Justice Department's Antiterrorism Initiatives.' American University Law Review 51: 1081-133.

Wilkinson, Paul 2001. Terrorism versus Democracy. New York, NY: Frank Cass Publishers. 